\title{
Validation of the COMP-CRI Scale: New Job Competencies in Times of Crisis
}

Submitted 14/10/21, 1st revision 12/11/21, 2nd revision 24/11/21, accepted 10/12/21

\begin{abstract}
Paulina Guerra Guerra ${ }^{1}$, Gilda Moreno Proaño ${ }^{2}$
Abstract:

Purpose: The Covid-19 pandemic evidenced the need for workers to develop skills to cope with changes, and in turn, for companies to create employment strategies. "Being a resilient company implies having the capacity (in terms of knowledge, skills, and attitudes) to survive changing, unpredictable, or directly unfavorable situations" that allow adequate work management. Therefore, this study aims to validate a scale of job competencies in times of crisis, which allows identifying the capacities, knowledge, skills, and attitudes of employees to manage the training of staff in the future.

Design/Methodology/Approach: The present investigation establishes the Scale of Work Competencies in Crisis (COMP-CRI) as a new solid psychometric instrument. The COMPCRI scale was validated after collecting data from 401 workers belonging to SMEs (small and medium-sized enterprises) from different provinces of the Highlands of Ecuador. The study design, having a descriptive scope, was non-experimental and longitudinal. Factor structures, reliability, and validity scores were also examined with the help of the SPSS-21 statistical program. Similarly, it included content validity through expert judgment, confirmatory factor analysis, reliability with Cronbach's Alpha, and intra-observer reliability was evaluated with the Kappa index.

Findings: From this, the content analysis was carried out through the judgment of experts. The first review of the questions was obtained with nine dimensions and 27 questions. The confirmatory factor analysis used the Principal Components method and the anti-imagen test. Practical Implications: This study contributes directly to the construction of new literature; although the study of competencies is comprehensive, it is essential to know which competencies are critical for the success or failure of a business.

Originality/Value: The COMP-CRI Scale develops competencies that were not observed before, such as the appropriate management of social networks. Nowadays, small and medium-sized companies have increasingly found the need for the owners of the companies and their workers to promote their business through the use of social networks.
\end{abstract}

Keywords: Employment strategies, training, work management.

JEL Classification: M53, M54.

Research type: Research article.

Acknowledgments: We thank the Research Department of the Indoamérica Technological University for funding and monitoring this research project.

${ }^{1}$ Docente de la Carrera de Psicología, Universidad Tecnológica Indoamérica, Quito-

Ecuador,paulinaguerra@uti.edu.ec;

${ }^{2}$ Universidad Tecnológica Indoamérica, Quito-Ecuador; 


\section{Introduction}

The Covid-19 pandemic has highlighted the accelerated changes at the organizational level, changes that undoubtedly modify the organizational structure of each company, some of them more strengthened than others will manage to overcome the crisis and adequately face emerging situations. In this context, small and medium-sized enterprises (SMEs) are not an exception, since due to their characteristics, they would be the ones that receive the most forceful impact that this new pandemic entails in the first instance (Huilcapi et al., 2020).

There is no controversy in stating that there have always been entrepreneurs and businesspeople, the former being understood as those people who voluntarily decide to take the initiative to undertake a project that eventually leads to the establishment of enterprises or triggers other entrepreneurial projects. By businesspeople, we understand those who are dedicated to managing companies with a partial or total shareholding. While entrepreneurship seems to be strongly associated with very personal aptitudes and attitudes that can nevertheless be enhanced and stimulated by society, and particularly by the State, the businessman responds to a role for which he can be educated, trained, and coached, of course, without discarding that this subject must possess management skills (Linares, 2020).

Nowadays, there have been great changes in different areas, in communications, the knowledge economy, and the labor market, which trigger flexible jobs that reveal new needs of employers, who must compete in an increasingly insecure context, as well as future workers, who seek success in their professional career and self-realization through work (Blustein et al., 2008; Do Cebu and Moreno, 2010).

Thus, labor competencies become one of the main axes for the subsistence of organizations. Given the existing skills gap in the market, both in knowledge and professional skills (soft skills) and attitudes, companies must assume a greater role (Masclans and Canals, 2020). The arrival of the next horizons of the post-COVID-19 era could be characterized as the era of the "urgency of the moment." Therefore, the competition here is about the ability not to lose sight of the actions that might be necessary for tomorrow (Buheji, 2020).

Levenson (2020) states that this pandemic could have a series of phases and, therefore, an emergent reaction is needed, followed by a reflection on the challenges that arise. As the world strives to resume its activity towards better productivity and progressive growth, it would have to face the crisis and re-adjust to the prerequisites of the new normal, in which we would witness changes in the speed and quality of workers training. Organizations would have as part of their vision the care for the worker's well-being in exchange for a high demand for employability competencies. 
Almost all leading organizations would work on retraining their employees or recruiting according to the requirements of the new normal (Meister, 2020). By the preceding, the objective of this research was to build and test the validity and reliability properties of the COMP-CRI Scale, trying to make it a valuable tool, both for use in research activities and training programs.

\section{Literature Review}

According to Gil (2007), he considers that the labor competency required for a job position must be carried out in work performance situations; that is by verifying knowledge, skills, and values in actual practices; since the evaluation of competencies discriminates those techniques that are based on the behavior of people in the workplace.

Currently, some instruments allow the identification and evaluation of job competencies, most of which entail an adaptation of personality traits to the language of competency. One of them is the COMPETEA, which was created to be a test designed to assess competencies and not personality traits (Arribas, 2015).

Another method used when evaluating labor competencies is the Assessment Centre, which has advantages in personnel management, due to the flexibility and easy adaptability of the exercises to different cultures; being, in addition, the most suitable for evaluating people who occupy high positions; as it changes the traditional evaluation of managers; however, it presents a high cost for the implementation of the exercises, infrastructure, and interpretation of the results (Torres, 2014).

There are undoubtedly several techniques for collecting information on labor competencies as shown in Table 1, without neglecting that the interview is the primordial one in any process of recruitment or promotion of personnel, in this case, referring to the competencies, it is usual to perform it with the BEI or critical incident interview. It is a semi-structured interview in which the interviewer inquires about recent experiences lived by the interviewee to obtain concrete behaviors in as much detail as possible to codify them in competencies (Alles, 2006).

\section{Research Methodology}

Thus, according to the above mentioned, the COMP-CRI Scale originates from the critical-incidents method, through a selection of critical competencies determined through a previous qualitative study where the necessary labor competencies to face crises were identified; considering that companies are constantly facing unstable periods not only due to events such as the Covid-19 pandemic but also due to situations inherent to an economy in crisis. Therefore, this study's objective is to validate the COMP-CRI scale of labor competencies in times of crisis, with which it 
is possible to identify the worker's competencies and thus strengthen them to improve their performance.

Table 1. Data collection techniques

Source: Gil Flores, 2007.

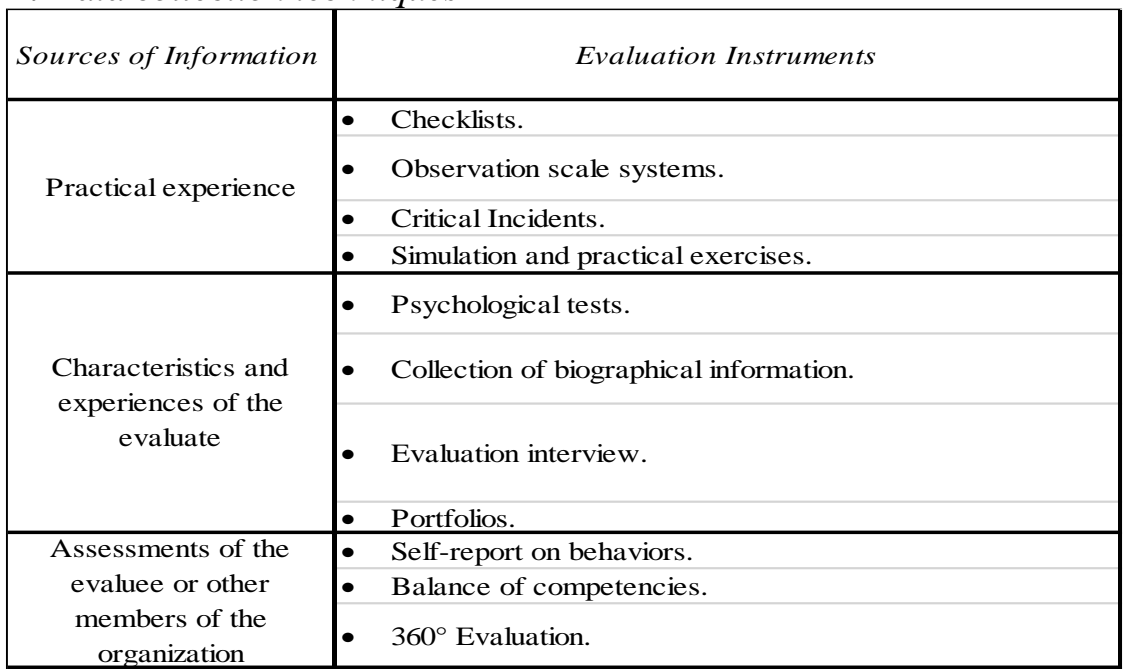

The following are the stages that were carried out for the construction of the COMPCRI Scale according to Hogan's (2004) methodological suggestions for the construction of the tests:

A.- Literature review and operationalization of the construct. - A detailed search and analysis of various theories and research were conducted to delimit the construct of the concept of competencies theoretically; in addition, a focus group was conducted in a previous study developed within the framework of this research project, in which the competencies that would constitute the scale were determined through experts in the area and owners of SMEs.

B.- Preparation of the items. - A preliminary set of 27 items was drafted to operationalize each of the variables. The COMP-CRI instrument was designed in the first instance with nine dimensions classified into soft and complex competencies. The total number of competencies to be evaluated was nine: Orientation to Results, Relationship Building, Vision and Anticipation, Decision Making, Resilience, Emotional Intelligence, Creativity, Initiative, and Social Networks.

The recommendations of Matesanz, (1997) were considered for the wording of the statements, which are clear, simple, and understandable for the participants. Likewise, the questions were ordered and interleaved. Each question was composed of 4 items, presenting different situations, with a score based on the competency model $A=4 B=3$ $\mathrm{C}=2 \mathrm{D}=1$. 
C.- Analysis by expert judgment. - The content validity was analyzed through the expert judgment method, with the participation of 5 specialists in the subject of study, who judged each item considering its formal quality (semantic clarity, syntactic correctness, and adequacy to the population) and with their contribution, observations, and suggestions, all the questions and answers were analyzed until they were rewritten.

D. - Data analysis. - In the first instance, the preliminary version of the test, consisting of 27 items, was applied to a non-probabilistic sample composed of 401 people, 217 men $(51.62 \%)$ and 184 women $(48.37 \%)$, aged between 19 and 51 years $(\mathrm{M}=32.5)$. The education level of the participants was as follows: no education (4.48\%), high school $(35.16 \%)$, third level $(39.15 \%)$, fourth level $(21.19 \%)$. In high position $(32.91 \%)$, medium position $(32.41 \%)$, low position $(34.66 \%)$.

The length of service in the position among the participants consisted of 1 to 5 years $(66.83 \%), 6$ to 9 years $(18.70 \%)$, more than ten years $(14.21 \%)$. (14,21\%). The construct validity was determined by factor analysis, using the anti-image correlation method and Principal Components, Cronbach's Alpha, split-half analysis, Kappa stability index.

\section{Results and Discussion}

In the first instance, a normality test was performed, to verify the distribution of the data where the alternate hypothesis was accepted where $\mathrm{p} \leq .000$ (Table 2).

Table 2. Tests of Normality

\begin{tabular}{|c|c|c|c|c|c|c|}
\hline \multicolumn{7}{|c|}{ Tests of Normality } \\
\hline & \multicolumn{3}{|c|}{ Kolmogorov-Smirnov $^{\mathrm{a}}$} & \multicolumn{3}{|c|}{ Shapiro-Wilk } \\
\hline & Statistic & \begin{tabular}{l|l}
$\mathrm{df}$ &
\end{tabular} & Sig. & Estadístico & df & Sig. \\
\hline \begin{tabular}{|l|} 
Orientation to \\
results total
\end{tabular} & .164 & 398 & .000 & .921 & 398 & .000 \\
\hline $\begin{array}{l}\text { Social } \\
\text { networks } \\
\text { total }\end{array}$ & .145 & 398 & .000 & .940 & 398 & .000 \\
\hline $\begin{array}{l}\text { Relationship } \\
\text { building total }\end{array}$ & .188 & 398 & .000 & .897 & 398 & .000 \\
\hline $\begin{array}{l}\text { Vision and } \\
\text { anticipation } \\
\text { total }\end{array}$ & .141 & 398 & .000 & .934 & 398 & .000 \\
\hline $\begin{array}{l}\text { Decision } \\
\text { making total }\end{array}$ & .142 & 398 & .000 & .940 & 398 & .000 \\
\hline Creativity total & .172 & 398 & .000 & .914 & 398 & .000 \\
\hline $\begin{array}{l}\text { Resilience } \\
\text { total }\end{array}$ & .171 & 398 & .000 & .935 & 398 & .000 \\
\hline $\begin{array}{l}\text { Emotional } \\
\text { intelligence } \\
\text { total }\end{array}$ & .181 & 398 & .000 & .896 & 398 & .000 \\
\hline Iniciative total & .167 & 398 & .000 & .917 & 398 & .000 \\
\hline
\end{tabular}

Source: Own creation. 
After validating this analysis, the Bartlett's test of sphericity was carried out ( $\mathrm{df}=$ $1205 ; \mathrm{p} \leq .000)$ in order to determine if the data fitted the factor analysis as shown in (Table 3); as well as the Kaiser-Meyer-Olkin Index (KMO) (.80). If the index was greater than .7, factor analysis was justified.

Table 3. KMO and Barlett test

KMO and Bartlett tests

\begin{tabular}{|l|l|r|}
\hline \multicolumn{2}{|l|}{ Kaiser-Meyer-Olkin Measure } & .800 \\
Bartlett's test & Aprox. Chi- & 1205.239 \\
of sphericity & square & 210 \\
\cline { 2 - 3 } & df & .000 \\
\hline
\end{tabular}

Source: Own creation.

In addition, the criterion of a load equal to or greater than .30 was considered to consider an item as representative of a factor, as shown in Table 4. In this way, the factors have good values, as shown in the anti-image table (Table 5), according to the recommendations of Tabachnick and Fidell (1989). Thus, based on the results described the items that did not agree with the specified criteria were eliminated, coinciding with Cronbach's Alpha index, leaving the scale composed of 21 items.

Table 4. Factor analysis - table of communalities

\begin{tabular}{|l|r|r|}
\hline \multicolumn{3}{|c|}{ Communalities } \\
\hline Question 2 & Initial & Extraction \\
\hline Question3 & 1.000 & .678 \\
\hline Question4 & 1.000 & .744 \\
Question6 & 1.000 & .716 \\
\hline Question7 & 1.000 & .693 \\
\hline Question8 & 1.000 & .609 \\
\hline Question10 & 1.000 & .603 \\
Question 12 & 1.000 & .614 \\
\hline Question 13 & 1.000 & .539 \\
\hline Question14 & 1.000 & .647 \\
\hline Question15 & 1.000 & .511 \\
\hline Question16 & 1.000 & .656 \\
\hline Question17 & 1.000 & .820 \\
\hline Question18 & 1.000 & .541 \\
\hline Question 19 & 1.000 & .578 \\
\hline Question 20 & 1.000 & .512 \\
\hline Question 22 & 1.000 & .676 \\
\hline Question 24 & 1.000 & .594 \\
\hline Question 25 & 1.000 & .555 \\
\hline Question 26 & 1.000 & .657 \\
\hline Question 27 & 1.000 & .538 \\
\hline Extraction Method: Principal Axis Factoring & \\
\hline
\end{tabular}

Source: Own creation. 
Table 5. Factorial Analysis anti-image matrix

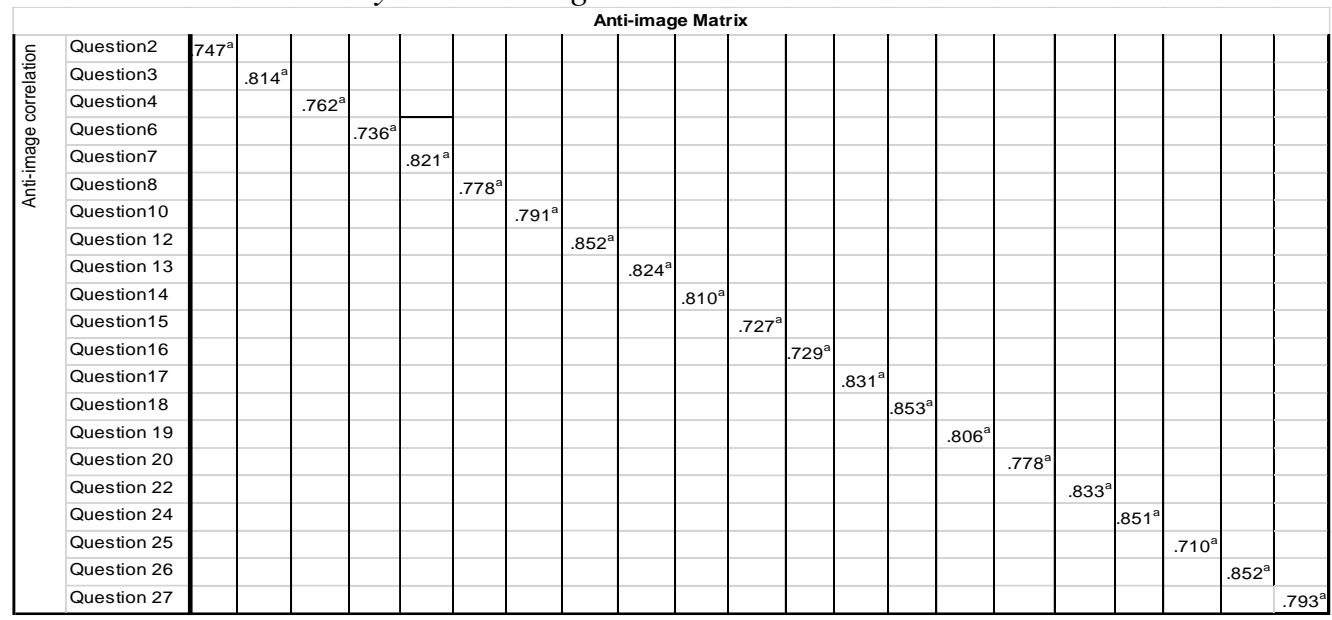

Source: Own creation.

To assess the reliability of the Inventory, the Cronbach's Alpha internal consistency analysis was performed with a value of (0.78)), which is considered acceptable (George and Mallery, 2010); this analysis allowed the elimination of some inconsistent questions, leaving a total of 20 questions (Table 6).

Table 6. Reliability analysis

\begin{tabular}{|c|c|c|c|c|c|}
\hline & \multicolumn{4}{|c|}{ Reliability Statistics } & \\
\hline & \multicolumn{2}{|c|}{$\begin{array}{c}\text { Cronbach's } \\
\text { Alpha }\end{array}$} & \multicolumn{2}{|c|}{$\mathrm{N}$ of items } & \\
\hline & \multicolumn{2}{|r|}{.781} & \multicolumn{2}{|r|}{20} & \\
\hline \multicolumn{6}{|c|}{ Total element statistics } \\
\hline & $\begin{array}{c}\text { Scale mean if } \\
\text { the element } \\
\text { has been } \\
\text { deleted }\end{array}$ & \multicolumn{2}{|c|}{$\begin{array}{c}\text { Scale } \\
\text { variance if the } \\
\text { element has } \\
\text { been deleted }\end{array}$} & $\begin{array}{c}\text { Corrected } \\
\text { element- total } \\
\text { correlation }\end{array}$ & $\begin{array}{l}\text { Cronbach's } \\
\text { Alpha if the } \\
\text { element has } \\
\text { been deleted }\end{array}$ \\
\hline Question2 & 62.9068 & \multicolumn{2}{|c|}{52.590} & .214 & .780 \\
\hline Question3 & 62.8892 & \multicolumn{2}{|r|}{50.639} & .307 & .775 \\
\hline Question4 & 62.7179 & \multicolumn{2}{|r|}{51.557} & .274 & .776 \\
\hline Question6 & 62.8564 & \multicolumn{2}{|r|}{51.154} & .302 & .774 \\
\hline Question7 & 62.7028 & \multicolumn{2}{|r|}{50.381} & .434 & .766 \\
\hline Question8 & 62.7884 & \multicolumn{2}{|r|}{51.359} & .319 & .773 \\
\hline Question10 & 62.5995 & \multicolumn{2}{|r|}{51.407} & .337 & .772 \\
\hline Question 12 & 62.7607 & \multicolumn{2}{|r|}{50.097} & .373 & .770 \\
\hline Question 13 & 62.6902 & \multicolumn{2}{|r|}{51.305} & .330 & .773 \\
\hline Question14 & 62.7557 & \multicolumn{2}{|r|}{49.902} & .373 & .770 \\
\hline Question15 & 62.9622 & \multicolumn{2}{|r|}{50.935} & .283 & .776 \\
\hline Question17 & 62.7960 & \multicolumn{2}{|r|}{49.925} & .411 & .767 \\
\hline Question 18 & 62.8589 & \multicolumn{2}{|r|}{50.162} & .319 & .774 \\
\hline Question 19 & 62.6196 & \multicolumn{2}{|r|}{51.964} & .301 & .774 \\
\hline Question 20 & 62.6171 & \multicolumn{2}{|r|}{50.606} & .396 & .769 \\
\hline Question 22 & 62.6549 & \multicolumn{2}{|r|}{50.954} & .357 & .771 \\
\hline Question 24 & 62.6977 & \multicolumn{2}{|r|}{48.838} & .535 & .759 \\
\hline Question 25 & 62.8388 & \multicolumn{2}{|r|}{50.504} & .332 & .773 \\
\hline Question 26 & 62.5642 & \multicolumn{2}{|r|}{51.211} & .377 & .770 \\
\hline Question 27 & 62.7280 & \multicolumn{2}{|r|}{51.714} & .314 & .774 \\
\hline
\end{tabular}

Source: Own creation. 
In addition, the split-half analysis was conducted with which the Cronbach's Alpha was verified through the unequal length Alpha $=(.78)$ as shown in the following Table 7.

Table 7. Split-half reliability analysis method

\section{Reliability Statistics}

\begin{tabular}{|c|c|c|c|}
\hline \multirow{5}{*}{$\begin{array}{l}\text { Cronbach's } \\
\text { Alpha }\end{array}$} & \multirow[t]{2}{*}{ Part 1} & Value & .630 \\
\hline & & Nof items & $11^{\mathrm{a}}$ \\
\hline & \multirow[t]{2}{*}{ Part 2} & Value & .650 \\
\hline & & $N$ of items & $10^{b}$ \\
\hline & \multicolumn{2}{|c|}{ Total N of items } & 21 \\
\hline \multicolumn{3}{|c|}{ Correlation between forms } & .644 \\
\hline \multirow{2}{*}{$\begin{array}{l}\text { Spearman- } \\
\text { Brown }\end{array}$} & \multicolumn{2}{|c|}{ Equal length } & .784 \\
\hline & \multicolumn{2}{|c|}{ Unequal length } & .784 \\
\hline \multicolumn{3}{|c|}{ Guttman Split-half Coefficient } & .783 \\
\hline
\end{tabular}

a. The items are: Question2, Question3, Question4,

b. The items are: Question 15, Question16, Question 17,

\section{Source: Own creation.}

Finally, the test retest was carried out with a time difference of 1 month, it was done through stability analysis using the Kappa index where the following values were obtained Orientation to results $=0.84$, Relationship building $=0.84$, Vision and anticipation $=0.84$, Decision making $=0.85$, Creativity $=0.85$, Resilience $=0.85$, Emotional Intelligence $=0.89$, Social Networks $=0.85$ as shown in Table 8 .

Table 8. Stability result of the Kappa index test.

\begin{tabular}{|c|c|c|}
\hline \multicolumn{3}{|c|}{ Orientation to results test-retest } \\
\hline & Value & $\begin{array}{l}\text { Asymptotic } \\
\text { standard } \\
\text { error }\end{array}$ \\
\hline \begin{tabular}{|l|l|} 
Measure of & Kappa \\
agreement & \\
\end{tabular} & .847 & .020 \\
\hline $\mathrm{N}$ of valid cases & 399 & \\
\hline \multicolumn{3}{|c|}{ a. Not assuming the null hypothesis. } \\
\hline \multicolumn{3}{|c|}{ b. Using the asymptotic standard error assuming the null } \\
\hline \multicolumn{3}{|c|}{ Relationship building test-retest } \\
\hline & Value & $\begin{array}{l}\text { Asymptotic } \\
\text { standard } \\
\text { error }\end{array}$ \\
\hline \begin{tabular}{|l|l|} 
Measure of & Kappa \\
agreement & \\
\end{tabular} & .847 & .020 \\
\hline $\mathrm{N}$ of valid cases & 399 & \\
\hline
\end{tabular}




\begin{tabular}{|l|r|r|}
\hline \multicolumn{3}{|c|}{ Vision and anticipation test-retest } \\
\hline & \multicolumn{1}{|c|}{ Value } & $\begin{array}{c}\text { Asymptotic } \\
\text { standard } \\
\text { error }\end{array}$ \\
\hline $\begin{array}{l}\text { Measure of Kappa } \\
\text { agreement }\end{array}$ & .842 & .020 \\
\hline N of valid cases & 400 & \\
\hline
\end{tabular}

a. Not assuming the null hypothesis.

b. Using the asymptotic standard error assuming the null

Decision making test-retest

\begin{tabular}{|l|r|c|}
\hline & Value & $\begin{array}{c}\text { Asymptotic } \\
\text { standard } \\
\text { error }\end{array}$ \\
\hline $\begin{array}{l}\text { Measure of Kappa } \\
\text { agreement } \\
\text { N of valid cases }\end{array}$ & .857 & .019 \\
\hline
\end{tabular}

a. Not assuming the null hypothesis.

b. Using the asymptotic standard error assuming the null

\begin{tabular}{|l|r|c|}
\hline \multicolumn{2}{|c|}{ Creativity test-retest } \\
\hline & \multicolumn{1}{|c|}{ Value } & $\begin{array}{c}\text { Asymptotic } \\
\text { standard } \\
\text { error }\end{array}$ \\
\hline $\begin{array}{l}\text { Measure of Kappa } \\
\text { agreement }\end{array}$ & .855 & .020 \\
\hline N of valid cases & 400 & \\
\hline
\end{tabular}

a. Not assuming the null hypothesis.

b. Using the asymptotic standard error assuming the null

Social networks test-retest

\begin{tabular}{|l|r|r|}
\hline & \multicolumn{1}{|c|}{ Value } & \multicolumn{1}{|c|}{$\begin{array}{c}\text { Asymptotic } \\
\text { standard } \\
\text { error }\end{array}$} \\
\hline $\begin{array}{l}\text { Measure of Kappa } \\
\text { agreement } \\
\text { N of valid cases }\end{array}$ & .855 & .020 \\
\hline a. Not assuming the null hypothesis. & \\
\hline b. Using the asymptotic standard error assuming the null \\
\hline
\end{tabular}

\begin{tabular}{|l|r|r|}
\hline \multicolumn{3}{|c|}{ Emotional intelligence test-retest } \\
\hline & \multicolumn{1}{|c|}{ Value } & $\begin{array}{c}\text { Asymptotic } \\
\text { standard } \\
\text { error }\end{array}$ \\
\hline $\begin{array}{l}\text { Measure of Kappa } \\
\text { agreement }\end{array}$ & .893 & .017 \\
\hline N of valid cases & 400 & \\
\hline
\end{tabular}

a. Not assuming the null hypothesis.

b. Using the asymptotic standard error assuming the null 


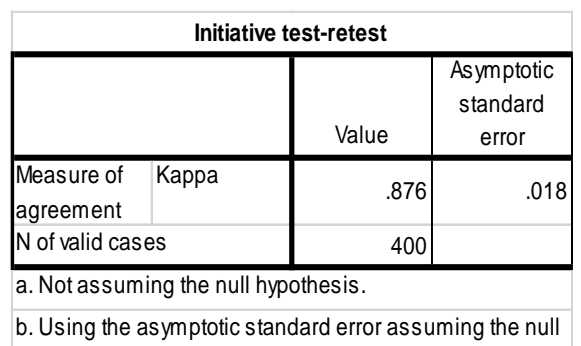

Source: Own creation.

The COMP-CRI Scale has proven to be a valid and reliable instrument and aims to assess job competencies in times of crisis significantly. Thus, according to the different types of indicators and methods implemented in the analysis of the Scale's psychometric properties, favorable evidence has been obtained regarding its internal consistency, structural validity, and stability. The internal consistency of the COMPCRI scales through the analysis of Cronbach's Alpha was acceptable, with an average of .78.

Likewise, it was possible to detect a nine-component factorial matrix, which provides a first theoretical validation assumed in the development of the Scale. The instrument is better aligned with new theoretical developments in training and supervision, including competency-based approaches (Falender and Shafranske, 2007; Gonsalvez, 2014; Pilling and Roth, 2014).

\section{Conclusions and Recommendations}

This study contributes directly to the construction of new literature; although the study of competencies is comprehensive, it is essential to know which competencies are critical for the success or failure of a business. The COMP- CRI Scale develops competencies that were not observed before, such as the appropriate management of social networks.

Nowadays, small, and medium-sized companies have increasingly found the need for the owners of the companies and their workers to promote their business through the use of social networks. During the economic and health crisis caused by COVID-19, they have resorted to a series of business strategies aligned with the use of e-commerce and massive use of social networks, not only the official ones but also those of the workers, who, assuming responsibility for their commitments to the SME, have established networks and relationships with customers, which have strengthened alternative forms of commercial exchange (González-Díaz and Flores Ledesma, 2020).

It is important to emphasize that in the future, it is expected to perform other statistical validations in order to contrast it with another instrument that allows confirming its validity, as well as the appropriate adaptation based on sociodemographic aspects such 
as the type of position, gender, type of company and other factors that could generate changes according to the competencies addressed in this study.

\section{References:}

Arribas, D. 2015. COMPETEA. Stomato-Pharyngology, 28(3), 309-311. https://doi.org/10.14821/stomatopharyngology.28.309.

Blustein, D.L., Kenna, A.C., Gill, N., DeVoy, J.E. 2008. The Psychology of Working: A New Framework for Counseling Practice and Public Policy. The Career Development Quarterly, 56, 294-308. doi: https://doi.org/10.1002/j.21610045.2008.tb00095.x.

Buheji, M. 2020. Socio-Economic Projects Spillovers and Their Influence on Communities Development. Review of European Studies, 12(1), 47. https://doi.org/10.5539/res.v12n1p47.

Coronavirus Crisis. Harvard Business Review. Coronavirus + Business, 6-11.

Falender, C.A., Shafranske, E.P. 2007. Competence in competency-based supervision practice: Construct and application. Professional Psychology: Research and Practice, 38(3), 232-240. doi:10.1037/0735-7028.38.3.232.

Falender, C.A., Shafranske, E.P. 2012. The importance of competency-based supervision and training in the 21st century: Why bother? Journal of Contemporary Psychotherapy, 42, 5-13.

George, D., Mallery, M. 2010. Using SPSS for Windows step by step: a simple guide and reference. Boston, MA: Allyn \& Bacon.

Gil Flores, J. 2007. La Evaluación De Competencias Laborales. Educación XX1, 10(0), 83106. https://doi.org/10.5944/educxx1.1.10.298.

Gonsalvez, C.J. 2014. Establishing supervision goals and formalizing a supervision agreement. In: Watkins Jr., C.E., Milne, D.L. (Eds.). The Wiley international handbook of clinical supervision, 282-307. West Sussex, England: John Wiley \& Sons Ltd. doi:10.1002/ 9781118846360.ch12.

González-Díaz, R. R., y Flores Ledesma , K. N. 2020. Cultura organizacional y Sustentabilidad empresarial en las Pymes durante crisis periodos de confinamiento social [Organizational culture and business sustainability in SMEs during crisis periods of social confinement]. CIID Journal,33(145), 352-365.

Hogan, T. 2004. Pruebas psicológicas: Una in- tro ducción práctica (Psychological testing: A practical introduction). México: Manual Mo- der no Editorial.

Huilcapi, N., Troya, K., Ocampo, W. 2020. Impacto del COVID-19 en la planeación estratégica de las pymes ecuatorianas (Impact of COVID-19 on the strategic planning of Ecuadorian SMEs). Recimundo, 4(3), 76-85. https://doi.org/10.26820/recimundo/4.(3).julio.2020.76-85.

Levenson, A. 2020. A Long Time Until the Economic New Normal, Leaders must learn from the pandemic now to position their companies to thrive in the next crisis. Sloan Review, MIT. https://sloanreview.mit.edu/article/a-long-time-until-the-economicnew-normal/.

Linares, R. 2020. La Pyme post COVID 19: ¿seguirá siendo un comodín entre el Estado y el Mercado? (Will it remain a wild card between the State and the Market?).

Masclans, R., Canals, J. 2020. María luisa blázquez roger masclans jordi canals. Las Competencias Profesionales Del Futuro: Un Diagnóstico y Un Plan de Acción Para Promover El Empleo Juvenil Después de La COVID-19 (María luisa 
blázquez roger masclans jordi canals. The Career Skills of the Future: A Diagnosis and an Action Plan to Promote Youth Employment After COVID-19). Retrieved from: chromeextension://ohfgljdgelakfkefopgklcohadegdpjf/https://www.iese.edu/es/wpcontent/uploads/sites/2/2020/07/IESE-Competencias-profesionales-del-futuro2020.pdf.

Matesanz, N.A. 1997. Evaluación estruc tu rada de la personalidad (Structured person- ality assessment). Madrid: Pirámide.

Meister, J. 2020. The Impact of The Coronavirus on HR and The New Normal of Work. Forbes. Retrieved from: https://www.forbes.com/sites/jeannemeister/2020/03/31/the-impact-of-thecoronavirus-on-hrand-the-new-normal-of-work/\#178b9d232b60.

Pilling, S., Roth, A.D. 2014. The competent clinical supervisor. In: Watkins Jr, C.E., Milne, D.L. (Eds.). The Wiley international handbook of clinical supervision, 20-37. West Sussex, England: John Wiley \& Sons Ltd. doi:10.1002/9781118846360.ch2.

Reese, M., Lang, N., Carlsson-Szlezak, P. 2020. Lead Your Business Through the Coronavirus Crisis. Boston Consulting Group, HBR.org.

Tabachnick, B.G., Fidell, L.S. 1989. Using multi variate statistics (2da. ed.). Nueva York: Harper \& Row.

Torres, G.P. 2014. Los Assessment Center: Una Metodología Para Evaluar Directivos. Revista de Estudios Avanzados de Liderazgo (The Assessment Center: A Methodology for Evaluating Managers. Journal of Advanced Leadership Studies), 1(1), 1-18. 
